2. Горелик В.А., Горелов А.Ф., Кононенко А.Ф. Анализ конфликтных ситуаций в системе управления. - М., 1991.

3. Дружсинин В.В., Конторов Д.С., Конторов М.Д. Введение в теорию конфликта. М.: "Радио и связь", 1989. - 288 с.

4. Моисеев Н.Н. Математические задачи системного анализа. - М.: Наука, 1981. $488 \mathrm{c}$. $200 \mathrm{c}$.

5. Дружинин В.В., Конторов Д.С. Системотехника. - М.: «Радио и связь», 1985. -

Надійшла 18.02.2009

УДК 681.3:621.375

Азаров О.Д., Богомолов С.В.

\title{
СКРЕМБЛЕР АНАЛОГОВИХ СИГНАЛІВ НА БАЗІ АЦП І ЦАП ІЗ ВАГОВОЮ НАДЛИШКОВІСТЮ
}

\section{Ветуп}

Скремблери аналогових сигналів являють собою одну 3 галузей масової технічної діяльності, в якій за допомогою електронних засобів здійснюється обробляння, накопичення, кодування, декодування і розповсюдження в електричній формі сигналів звукового діапазону частот.

У теперішній час способи перетворення та опрацювання мовних сигналів потребують аналого-цифрових пристроїв 3 досить високими характеристиками: динамічним діапазоном до 100-110 дБ, віднощення сигнал/шум - 96-112 дБ, коефіцієнтом нелінійних спотворень близько 0,001 $\div 0,002 \%$, спектр частот вхідного сигналу 16-20000 Гц, розрядність вихідного двійкового коду 14-18 розрядів і частота відліків 44,1 кГц [1]. АЦП і ЦАП є найрозповсюдженішими пристроями в аналого-цифрових системах.

Досягнення в розвитку цифрових технологій дозволили значно поліпшити якість опрацювання аналогових сигналів. Одним із шляхів цього напрямку є побудова і використання високолінійних, швидкодіючих АЦП і ЦАП із ваговою надлишковістю [2]. Одним із найефективніших шляхів створення перетворювачів форми інформації 3 високою лінійністю $\epsilon$ застосування методів самокалібрування на основі НПСЧ з використанням чисел Фібоначчі й «золотої пропорції»[3]. Застосування НПСЧ до того ж дозволяе здійснювати закриття інформації методами, які грунтуються на властивостях даних систем [3, 4].

\section{Актуальність}

У системах зв'язку відомо два основних методи скремблювання аналогових сигналів, що розрізняються по способу передачі по каналах зв'язку: аналогове скремблювання й дискретизація мови 3 наступним шифруванням. Під скремблюванням розуміється зміна характеристик мовного сигналу, таким чином, що отриманий модульований сигнал, маючи властивості нерозбірливості й невпізнанності, займає ту ж смугу частот, що й вихідний сигнал [5].

Автори пропонують побудову скремблерів аналогових сигналів і систему кодування на основі систем числення із ваговою надлишковістю. Використання даних систем числення забезпечує , по-перше, підвищення точності і швидкодії [6], по-друге, 3 точки зору короткочасного шифрування, робота в єдиному коді.

Скремблери всіх типів вносять спотворення у відновлений мовних сигнал, тому проектування скремблерів аналогових сигналів на базі АЦП і ЦАП із ваговою надлишковістю із застосуванням властивостей надлишкових систем числення $€$ актуальною. 


\section{Meта статті}

Метою досліджень $€$ аналіз можливостей побудови скремблера аналогових сигналів, шляхом використання НПСЧ, а також АЦП і ЦАП із ваговою надлишковістю на їх основі, що дозволяє підвищувати розбірливість та ототожнювати мовця за принципом «свій-чужий».

\section{Постановка задач}

1. Огляд систем числення із ваговою надлишковістю.

2. Рекомендації щодо побудови аналого-цифрового скремблера із застосуванням АЦП і ЦАП із ваговою надлишковістю.

\section{Розв'язання задач}

Огляд надлишково-позиційних систем числення (НПСЧ) та їх арифметико-числових властивостей дозволяє виділити такі дві групи: НПСЧ із дробовими вагами розрядів та НПСЧ із цілочисловими вагами розрядів [6]. У першій групі НПСЧ, призначеній для представлення дійсних чисел, будь-яке число А можна зобразити у вигляді:

$$
\mathrm{A}^{*}=\sum_{i=-\infty}^{n-1} a_{i} \alpha^{i}
$$

де і-номер розряду; $a_{i} \in\{0,1\}$ або $a_{i} \in\{1, \overline{1}\}$ - двійкова цифра в і-му розряді; $\alpha^{i}$ - вага i-го розряду; $\alpha$ - основа системи числення, значення якої знаходиться в межах

$1,0<\alpha<2,0 ;$ ( $\mathrm{n}-1)-$ номер старшого розряду.

При $\alpha=1$ вираз (1.1) представляє одиничну систему числення, а при $\alpha=2$ - двійкову систему числення. На практиці довжина розрядної сітки звичайно обмежується n розрядами. Тому в цьому випадку доцільно використовувати наближений вираз для натуральних чисел:

$$
\mathrm{N}^{*}=\sum_{0}^{n-1} a_{i} \alpha^{i}
$$

Відповідно до визначення, наведеного у [7], під основою НПСЧ вважається відношення ваг сусідніх розрядів: $\alpha=Q_{i} / Q_{i-1}$, де $Q_{i}=\alpha^{i} Q_{0}$ - значення ваги (фізичної величини) i-го розряду, а $Q_{0} \equiv 1$ - вага молодшого нульового розряду.

До НПСЧ із дробовими вагами розрядів, зокрема, відносяться системи числення «золотої р-пропорції», запропоновані О.П. Стаховим $[3,4]$. У НПСЧ на основі «золотої рпропорції» будь-яке натуральне число $N^{*}$ можна подати у вигляді:

$$
\mathrm{N}^{*}=\sum_{i=-n}^{n-1} a_{i} \alpha_{p}^{i}
$$

де $\alpha_{p}^{i}=\alpha_{p}^{i-1}+\alpha_{p}^{i-p-1}$ - і-та ступінь «золотої $p$-пропорції».

При $\mathrm{p}=0$ НПСЧ вироджується у двійкову систему числення, $p=1$ - систему «золотої пропорції», $p=\infty$ - одиничний код. Для НПСЧ характерна багатозначність представлення чисел. Це наочно можна продемонструвати на прикладі золотої системи числення, у якій $\alpha^{i}=\alpha^{i-1}+\ldots+\alpha^{i-2}$. Над розрядами кодів чисел у даній системі можна виконувати операції згорнення і розгорнення. Згорнення полягає в заміні нуля в $i$-му і одиниць у $(i-1)$-ому та $(i-2)$ ому розрядах їхніми інверсіями. Розгорнення - операція, зворотна згорненню. Зображення початкового відрізка натуральних чисел у золотій системі числення зручно здійснювати за допомогою операцій згорнення і розгорнення (табл. 1).

Прикладом НПСЧ із цілючисловими вагами можуть служити системи числення на основі $p$-чисел Фібоначчі, коли:

$$
\mathrm{N}^{*}=\sum_{0}^{n-1} a_{i} \varphi_{p}(i)
$$

де $\varphi_{p}(i)$ - вага і-го розряду, що дорівнює $i$-му $p$-числу Фібоначчі. При $p \geq 0$ р-числа Фібоначчі задаються рекурентним співвідношенням: 


$$
\varphi_{p}(i)=\left\{\begin{array}{l}
0, \text { при } \mathrm{i}<0, \\
1, \text { при } \mathrm{i}=0, \\
\varphi_{p}(i-1)+\varphi_{p}(i-p-1), \text { при } \mathrm{i}>0 .
\end{array}\right.
$$

Таблиця 1

Операції згорнення та розгорнення

\begin{tabular}{|c|c|c|c|c|c|c|c|c|}
\hline ваги розрядів & $\alpha^{3}$ & $\alpha^{2}$ & $\alpha^{I}$ & $\alpha^{0}$ & $\alpha^{-1}$ & $\alpha^{-2}$ & $\alpha^{-3}$ & $\alpha^{-4}$ \\
\hline $0=$ & 0 & 0 & 0 & 0 & 0 & 0 & 0 & 0 \\
\hline \multirow[t]{2}{*}{$1=$} & 0 & 0 & 0 & 1 & ${ }^{0}$ & $\begin{array}{l}0 \\
\uparrow\end{array}$ & 0 & 0 \\
\hline & 0 & 0 & 0 & 0 & 1 & 1 & 0 & 0 \\
\hline \multirow{2}{*}{$2=$} & 0 & 0 & $\iota^{0}$ & $\perp^{1}$ & \rfloor$^{1}$ & 1 & 0 & 0 \\
\hline & 0 & 0 & 1 & 0 & 0 & 1 & 0 & 0 \\
\hline
\end{tabular}

При $p \geq 0 \varphi_{p(i)}=2 \varphi_{p(i-l)}$ і вищенаведене представлення для $N^{*}$ вироджується у двійкову систему числення. При $p=1$ з'являється система числення Фібоначчі.

Слід зазначити, що введення інформаційної надлишковості у формі НПСЧ, дозволяє організувати процедуру самокалібрування і компенсації динамічних похибок ваг розрядів і використовувати ці принципи для побудови високолінійних швидкодіючих АЦП і ЦАП, точносні характеристики яких не погіршуються під час змінення умов зовнішнього середовища і функціонування протягом тривалих проміжків часу.

АЦП, що самокалібруються - це перетворювачі, високі метрологічні характеристики яких забезпечуються за рахунок автоматичного цифрового коригування похибок аналогових пристроїв [2]. Структурні рішення АЦП, що самокалібрується, відрізняються наявністю зворотних зв'язків, використовуваних при визначенні реальних характеристик аналогових пристроїв у спеціальному режимі роботи, названому самокалібруванням. Коригування результатів перетворення виконується під керуванням спеціального обчислювальнокеруючого блоку(ОКБ) АЦП, що самокалібрується (контролера).

Перевагою АЦЦ, що самокалібрується, $є$ можливість забезпечення високих технічних характеристик при знижених вимогах до елементної бази й технології виготовлення. Специфіка аналогових пристроїв АЦП, що самокалібрується, складається в можливості коригування ряду їхніх похибок, що спрощує ці пристрої.

Крім того, саме для АЦП порозрядного перетворення на основі надлишкових систем числення типу кодів Фібоначчі й «золотої пропорції» отримано найбільші успіхи в розвитку принципів самокалібрування та коригування статичних і динамічних похибок.

Структуру АЦП порозрядного врівноваження із ваговою надлишковістю, що калібрується зображено на рис. 1, у якій можна виділити: вхідний пристрій, пристрій дискретизації, пристрій квантування і цифровий ОКБ.

Для АЦП на основі «золотої пропорції» відносна похибка ваг розряду за рахунок технологічних, температурних, часових факторів може досягати до 23,6\% [2], що не приведе до пропусків кодів. Таким чином, $€$ можливість одержати точне значення вхідного 
аналогового сигналу.

У теперішній час для розробки АЦП порозрядного кодування широко застосовується цифрове коригування ЦАП [8]. Застосування НПСЧ у таких АЦП, побудованих на неточних елементах, дозволяє підвищувати лінійність і швидкодію.

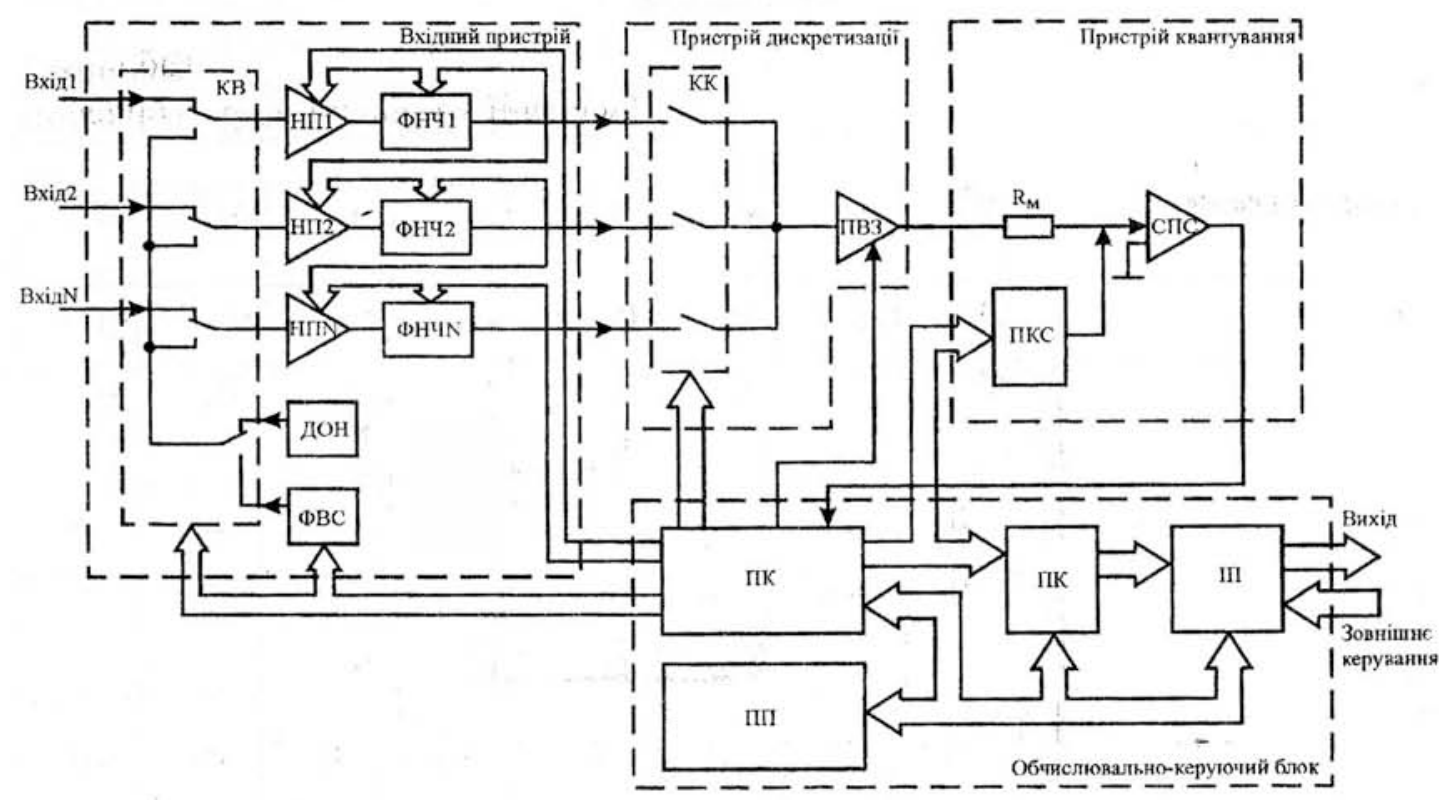

Рис. 1. Узагальнена структурна схема АЦП, що самокалібрується

Структурну систему високолінійного ЦАП, що самокалібрується наведено на рис. 2.

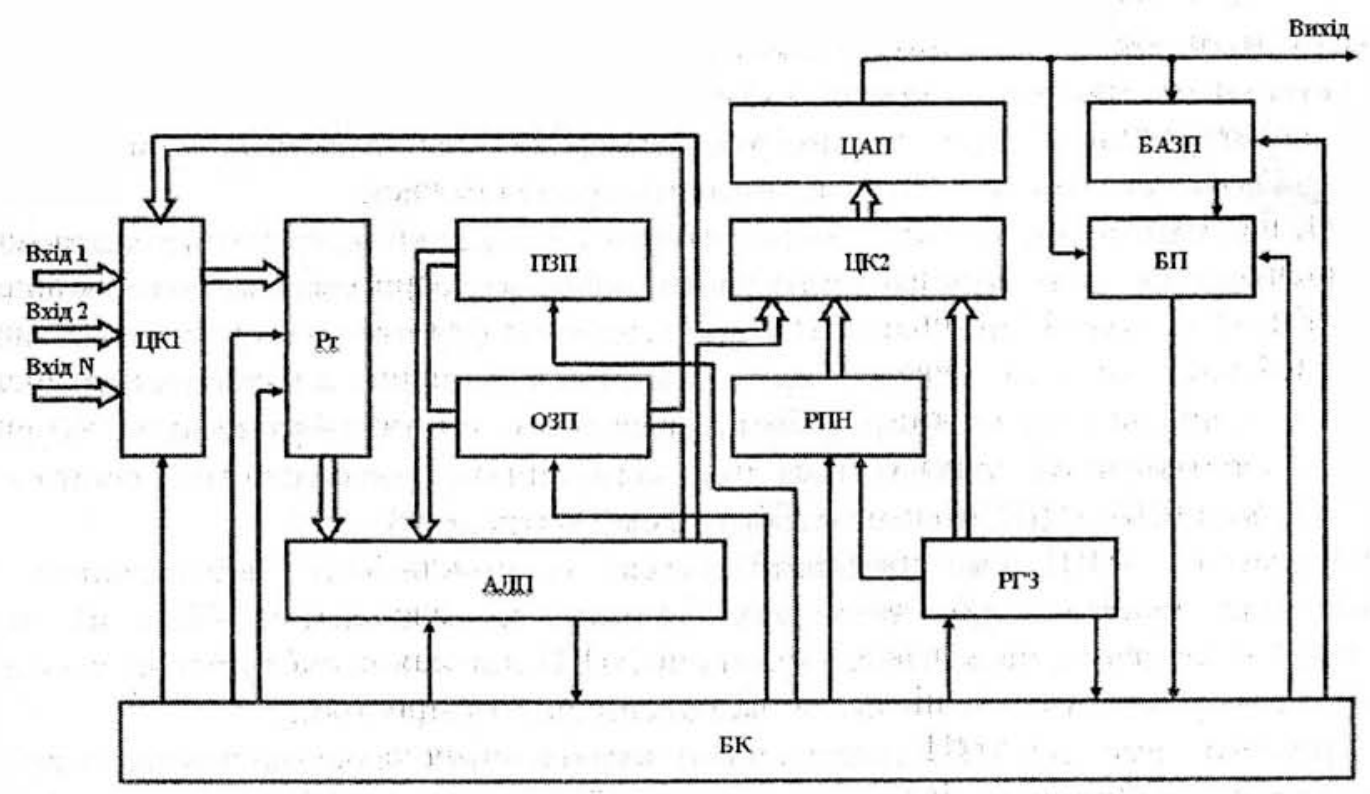

Рис. 2. Узагальнена структурна схема ЦАП, що самокалібрується

В наш час гостро стала проблема захисту інформації, і звукові сигнали є чи не найпершим об'єктом захисту. Існує багато методів захисту звукових сигналів як в аналоговій, так і в цифровій формі. Більшість 3 них досить складні і поотребують значних програмних і апаратних витрат. Проте існують випадки, коли потрібно швидко і без значних витрат “закрити” сигнал (наприклад команди переміщення військ під час бойових дій), при 
чому не $є$ критичною ступінь захисту, оскільки інформація дуже швидко втрачає цінність. Для цього застосовуються різні методи, які базується на передаванні по каналам зв'язку закодованого сигналу, що не дає можливості швидко розпізнати інформацію [5].

Найпоширенішою формою представлення аналогових сигналів $є$ представлення за допомогою імпульсно-кодової модуляції. Файл аналогового сигналу в цифровій формі, представлений значеннями амплітуди в певний відлік часу. Амплітуди представлені в двійковому коді і для відтворення цей код подається на двійковий ЦАП звукової карти.

Кодування аналогового сигналу за допомогою запропонованого скремблера полягає у перетворенні двійкового коду в код НПСЧ. В цьому випадку при відтворенні через двійковий ЦАП сигнал втратить розбірливість. Основа НПСЧ може бути змінена, тому кожного разу можна отримувати інше представлення аналогового сигналу що ускладнює його розшифрування. Також НПСЧ, зокрема «золоті $p$-пропорції», мають характерні особливості - після одиниці слідує не менше $p$ нулів, що дає додаткові можливості для кодування.

Запропонований алгоритм кодування мовних сигналів на основі НПСЧ представлено на рис. 3. У результаті роботи даного алгоритму отримаємо закодований сигнал. Декодування сигналу відбувається шляхом зворотного перетворення.

Для пояснення процесу скремблювання використаємо алгоритм табличного переводу 3 двійкового коду в код НПСЧ і навпаки. Для цього необхідно сформувати таблицю ваг розрядів НПСЧ і послідовно порівнювати значення ії елементів (починаючи найбільшого) 3 значенням амплітуди вхідного мовного сигналу. Приклад табличного перетворення числа 25 в НПСЧ на основі $p$-чисел Фібоначчі при $p=1,2,3,4$ приведено в табл. 2 .

Таблиця 2

Приклад перетворення числа в НПСЧ

\begin{tabular}{|c|c|c|c|c|c|c|c|c|c|c|}
\hline & \multicolumn{5}{|c|}{ Вага розряду } & \multirow{2}{*}{\multicolumn{5}{|c|}{$\begin{array}{c}\text { Код } \\
\text { p-числа Фібоначчі } \\
\text { в двійковій формі }\end{array}$}} \\
\hline & \multicolumn{4}{|c|}{ Р-числа Фібоначчі } & \multirow[t]{2}{*}{ двійкові } & & & & & \\
\hline & $\mathrm{P}=1$ & $\mathrm{P}=2$ & $\mathrm{P}=3$ & $\mathrm{P}=4$ & & $\mathrm{P}=1$ & $\mathrm{P}=2$ & $\mathrm{P}=3$ & $\mathrm{P}=4$ & Двійкова \\
\hline$\alpha^{0}$ & 1 & 1 & 1 & 1 & 1 & 1 & 0 & 1 & 0 & 1 \\
\hline$\alpha^{1}$ & 2 & 2 & 2 & 2 & 2 & 0 & 0 & 0 & 0 & 0 \\
\hline$\alpha^{2}$ & 3 & 3 & 3 & 3 & 4 & 1 & 0 & 0 & 0 & 0 \\
\hline$\alpha^{3}$ & 5 & 4 & 4 & 4 & 8 & 0 & 0 & 0 & 0 & 1 \\
\hline$\alpha^{4}$ & 8 & 6 & 5 & 5 & 16 & 0 & 1 & 1 & 1 & 1 \\
\hline$\alpha^{5}$ & 13 & 9 & 7 & 6 & & 0 & 0 & 0 & 0 & \\
\hline$\alpha^{6}$ & 21 & 13 & 10 & 8 & & 1 & 0 & 0 & 0 & \\
\hline$\alpha^{7}$ & & 19 & 14 & 11 & & & 1 & 0 & 0 & \\
\hline$\alpha^{8}$ & & & 19 & 15 & & & & 1 & 0 & \\
\hline & & & & 20 & & & - & & 1 & \\
\hline
\end{tabular}

Згідно табл. 2 в НПСЧ р-числа Фібоначчі 3 різною основою дозволяють отримати вихідні коди, що для різних основ $p$ різними кодами представляють одну й туж саму інформацію. Використовуючи властивість золотої р-пропорції, що після одиниці слідує не менше $p$ нулів, отримуємо ущільнені коди, які подано в табл. 3. Зміна $p$-значення призводить до зміни довжини ущільненого коду, а $p$ виступає в ролі ключа.

Цифрове представлення аналогових сигналів важливе насамперед можливістю нескінченного збереження і тиражування без втрати якості, а також "невибагливість" до каналів передачі даних, однак перетворення 3 аналогової форми в цифрову і навпаки неминуче призводить до часткової її втрати. 
Таблиця 3

Перетворення вихідного коду в ущільнений код

\begin{tabular}{|r|c|l|l|}
\hline \multicolumn{2}{|r|}{ Система числення } & Вихідний код & Ущільнений код \\
\hline \multicolumn{2}{|c|}{ Двійкова } & 11001 & - \\
\hline \multirow{3}{*}{$\begin{array}{c}\text { Р-числа } \\
\text { Фібоначчі }\end{array}$} & $\mathrm{P}=1$ & 1000101 & 10011 \\
\cline { 2 - 4 } & $\mathrm{P}=2$ & 10010000 & 1100 \\
\cline { 2 - 4 } & $\mathrm{P}=3$ & 100010001 & 111 \\
\cline { 2 - 4 } & $\mathrm{P}=4$ & 1000010000 & 11 \\
\hline
\end{tabular}

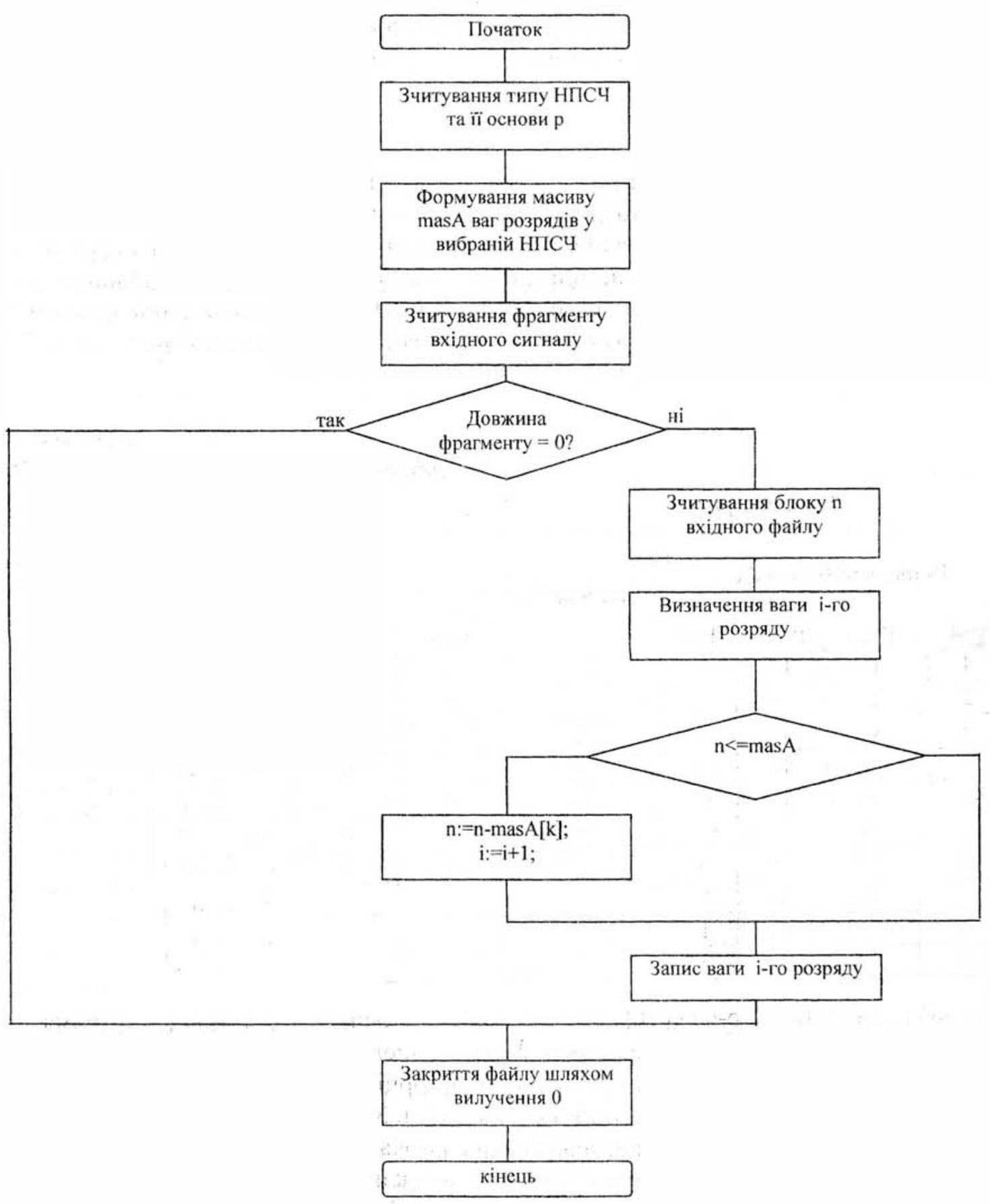

Рис. 3. Блок-схема алгоритму кодування мовних сигналів 
Поєднання високолінійних АЦП і ЦАП із ваговою надлишковістю та властивостей НПСЧ дозволяє побудувати скремблер мовних сигналів, структурну схему якого зображено на рис. 4.

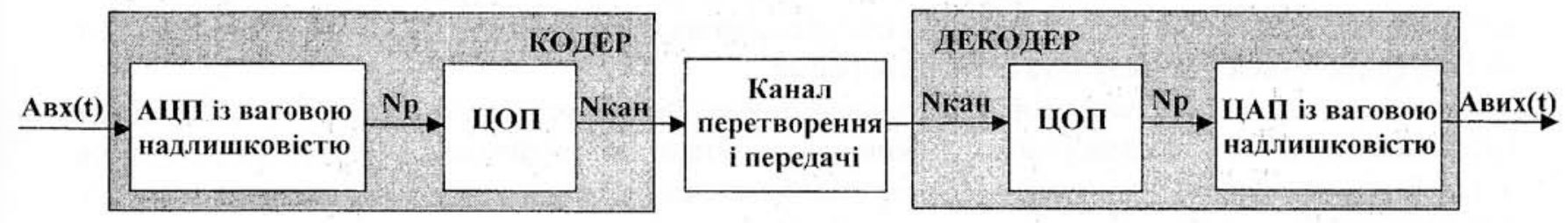

Рис. 4. Узагальнена структурна схема скремблера аналогових сигналів

Цифровий обчислювальний пристрій (ЦОП) забезпечує пряме перетворення робочого коду $\mathrm{Np}$ у канальний код Nкан та зворотне перетворення канального Nкан в робочий Np.

У загальному випадку склад системи скремблювання аналогових сигналів визначається конкретним призначенням та умовами ії функціонування. Але ядро системи, що складає базу високолінійних канальних АЦП і ЦАП на основі НПСЧ буде незмінним. При цьому, доповнення необхідними аналоговими і цифровими вузлами, визначає необхідний склад як аналого-цифрових модулів, так і цифроаналогових у цілому.

У випадку скремблювання мовних сигналів, які представлені у двійковому цифровому коді, дану систему необхідно доповнити перетворювачами кодів, для того, щоб забезпечити зв'язок р-кодів із звичайними двійковими кодами [9,10]. Структурні схеми пристроїв прямого і зворотного перетворення кодів наведено на рис.5.

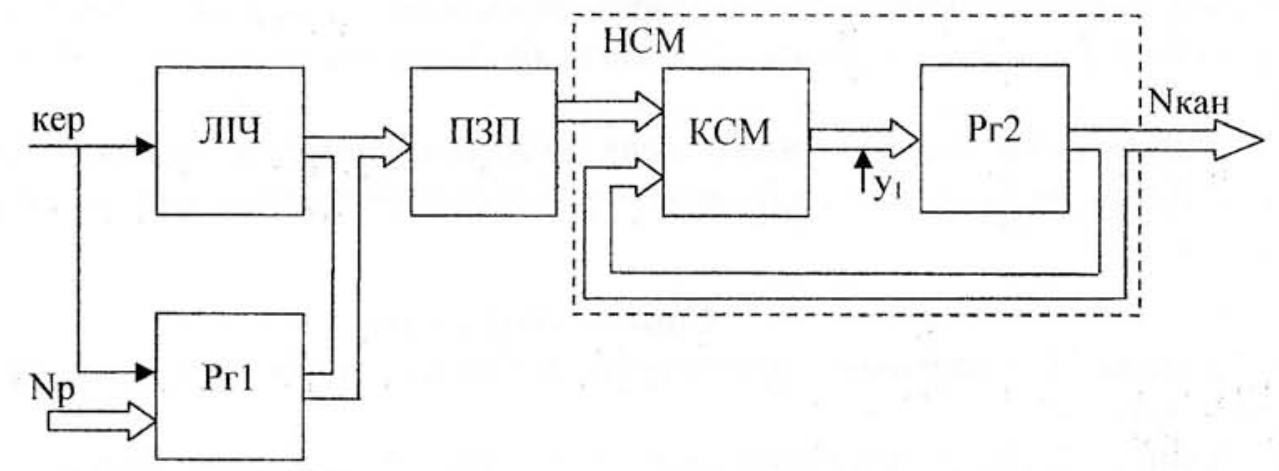

a)

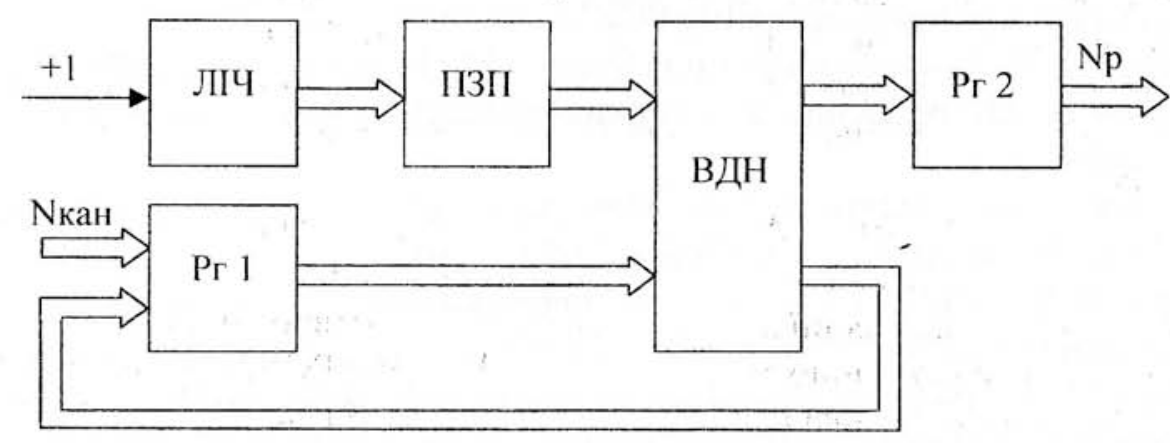

б)

Рис. 5. Структурна схема пристрою для перетворення кодів:

a) коду результату $\rightarrow$ канальний; б) канальний код $\rightarrow$ двійковий. 
При прямому перетворенні вхідний двійковий код, який необхідно перетворити у ркод Фібоначчі, записується в регістр Рг1. В ПЗП зберігаються кодові еквіваленти $p$-кодів Фібоначчі двійковим кодам. Лічильник ЛІч формує адреси кодових еквівалентів, а в нагромаджуючому суматорі НСМ, який побудовано на основі комбінаційного суматора КСМ та Рг2, формується код результату перетворення.

При зворотному перетворенні вхідний р-код Фібоначчі записується в Рг 1, віднімач ВДН забезпечує порівняння р-коду Фібоначчі із двійковими еквівалентами, що зберігаються в ПЗП. Лічильник ЛІЧ та регістр зсуву Рг 2 зебезпечують формування коду результату перетворення.

Слід зазначити, що використання АЦП і ЦАП на основі НПСЧ також дає певні переваги перед двійковими перетворювачами інформації. Так, зменшений час врівноважування дозволяе підняти частоту дискретизації або збільшити кількість оброблюваних каналів при роботі в багатоканальному режимі. Незважаючи на спрощену технологію виготовлення аналогових вузлів, підсумкова похибка перетворення як ЦАП, так i АЦП на основі НПСЧ може бути досить низькою при роздільності не менше 16-18 двійкових розрядів. Це досягається, зокрема, калібруванням ваг розрядів і корекцією статичних похибок, що здійснюється обчислювальним пристроєм. Також використання властивостей НПСЧ, дозволяє кодувати/декодувати мовні сигнали з метою захисту інформації.

\section{Висновки}

1. Показано перспективність побудови скремблерів на основі високолінійних АЦП і ЦАП із ваговою надлишковістю, що самокалібруються, при цьому можна застосовувати єдиний код, як для покращення динамічних і статичних характеристик АЦП і ЦАП, так і для, власне, кодування сигналу, що передається по каналу зв'язку. Це дозволяє відмовитися від використання складних процедур цифрового обробляння і значно зменшити спотворення сигналу, особливо під час перетворення сигналів за допомогою АЦП і ЦАП із ваговою надлишковістю.

2. Підвищення якості сигналів після кодування, передачі та декодування дозволяє зберегти не тільки розбірливість, а й можливість ототожнювати мовця за принципом «свійчужий».

\section{Список літератури}

1. Шкрітек П. Справочное руководство по звуковой схемотехнике: Пер. с нем.-М.: Мир, 1991. - 446с.

2. Азаров О.Д., Крупельницький Л.В. Аналого-цифрові пристрої систем, що самокоригуються, для вимірювань і обробляння низькочастотних сигналів: Монографія. / Під заг. Ред. О.Д. Азарова. -Вінниця: УНІВЕРСУМ-Вінниця, 2005 - 167 с.

3. Стахов А. П. Коды золотой пропорции.- М.: Радио и связь, 1984.- 152с.: ил.

4. Стахов А. П. Введение в алгориитмическую теорю измирения.- М.: Советское радио, 1977.- $288 \mathrm{c}$.

5.Хорошко В.А., Чекатков А.А. Методы и средства защиты информации/Под ред. Ю.С. Ковтанюка - К.: Издательство Юниор, 2003. - 504c., ил.

6.Азаров О.Д. Основи теорії аналого-цифрового перетворення на основі надлишкових позиційних систем числення. Монографія. - Вінниця: УНІВЕРСУМ-Вінниця, 2004. - 260 с.

7.Карцев М.А. Арифметика цифрових машин. - М.: Наука, $1969-576$ с.

8.Азаров О.Д. Основи теорії аналого-цифрового перетворення на основі надлишкових позиційних систем числення. Монографія. - Вінниця: УНІВЕРСУМ-Вінниця, 2004. - 260 с.

9.Лужецький В. А. Високонадійні математичні Фібоначчі-процесори. Монографія Вінниця «УНІВЕРСУМ-Вінниця», 2000. - 248 с.

10.Майоров С.А., Новиков Г.И. Структура электронных вычислительных машин.

-Л.: Машиностроение. Ленингр. отд-ние, 1979 г. - 384c., ил. 